\title{
Application of performance appraisal system (PAS) attributes among first rater officers (FRO's): Issues and Implication
}

\author{
Jakheus Limasan $^{1 *}$, Rusli Ahmad ${ }^{2}$ and Nur Fatihah Abdullah Bandar ${ }^{3}$ \\ ${ }^{1,2,3}$ Universiti Malaysia Sarawak, 94300 Kota Samarahan, Sarawak, Malaysia
}

\begin{abstract}
This study aims to explore the first rater officers' perspectives on the application of performance appraisal attributes in performance appraisal system in a higher education institution in Sarawak. Six attributes were focused on the study namely clarification of the system, justification of the system, control criteria, employee participation, system management, and credibility of the assessor. The study uses a qualitative methodology using semi-structured interview techniques and data analysis in thematic approach. Three common issues are the limitation of the system's availability, insufficient scoring distribution towards lecturers who are involved in administrative work and limited capability of the server. Along with that, two critical issues are the subjective judgment of personality traits and limited utilization of the system. The implication raised based on the issues is work processes are interrupted, employee dissatisfaction and organizational image are affected. In conclusion, the issues within the performance appraisal system need to be taken seriously to avoid conflicts.
\end{abstract}

Keywords: Performance appraisal system attributes; General issues; Critical issues; First rater officer

Copyright: This is an open access article distributed under the terms of the Creative Commons Attribution-NonCommercialShareAlike 4.0 International (CC BY-NC-SA 4.0) license which permits unrestricted use, distribution, and reproduction in any medium, for non-commercial purposes, provided the original work is properly cited.

\section{BACKGROUND}

Job Performance appraisal is one of the most important activities in human resource management practices (Ahmad, Ismail \&

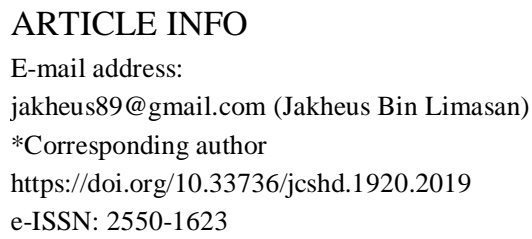

Manuscript received: 15 July 2019; Accepted: 6 September 2019; Date of publication: 30 September2019.
Wan Ismail, 2011). The impact of the performance appraisal system is very significant to the employee as it is related to the wage rate or wage that the employee will receive. In addition, Public Service Department (2010) emphasized that the performance appraisal system (PAS) is an important part of Human Resource Management (HRM). This statement is also supported by Shaari, Tang, Lim, Yusof and Khan (2008) who stated that PAS is an important aspect of HRM and is considered to 
be the core of an organization. In this regard, researchers point out that PAS is very important in determining the success of an organization because employees are the most important asset to be managed. At the same time, Kuvaas (2006) explained that the purpose of PAS is to look at the development of workers and organizations to have a stronger and more autonomous orientation.

According to Brooks (2006), the widespread use of this technology especially in the human resource information system is important for managing and improving organizational performance. There is no denying that many media are used within PAS. HRM itself uses ICT to manage and store data and workers' data within the organization. Soete (2001) indicated that every organization should carry out a performance evaluation either in the public or private sector as this is compulsory for the organization's sustainability. In addition, the importance of technology is very imperative especially in PAS and all attributes involved to evaluate the employee.

Therefore, in order to manage this very important resource, it is certain that aspects of an employee's PAS need to be taken more seriously. Performance appraisal is an important part of knowledge in performance management that has taken a long time in the organization and its importance has never been disputed by all. Ahmad and Shamsuddin (2011) stated that shareholders, management companies, trade unions and employees themselves believe that these activities are highly significant and need to be systematically and effectively implemented. Hence, this study was conducted to explore issues that arised from the perspective of first rater officer in a higher education institution.

\section{PROBLEM STATEMENT}

Performance appraisal is one of HRM's critical activities and it elevates many issues towards the organization (Veloo and Zolkepli, 2011). Apart from that, Public Service Department (2011) recommended the heads of departments and rater officers should optimally utilize the technology to achieve organizational objectives. Furthermore, Othman and Halim (2014) emphasized that by 2020 the government has targeted every university to become a hub of educational excellence in the international region. Accordingly, many things have been emphasized and among them is the requirement to reinforce information technology as well as communication skills within the organization. Besides that, Asiimwe and Lim (2010) indicated that user-friendly systems assist the users to navigate the portal seamlessly as well as strengthen the relationship and encouraging continuous distribution of information to users. The limited availability of the system had resulted in lack of quality in an interaction (Norsidah, 2014).

Public Service Department (2011) showed in the PAS guidelines that Rater Officers (RO) should create an objective, fair and transparent evaluation of the employees' career development. Folger and Kanovsky (1989) emphasized that rater officers should act more professional to identify facts by evaluating employee's achievements precisely based on valid and credible measurement criteria. Apart from that, Zulbasri and Bakar (2017) explained that a subjective assessment will lead to tension and conflicts until the activities become unpleasant and ineffective. In addition, Robert (1992) explained that the implementation of more subjective assessments trigger tension and 
cause PAS activity to become unpleasant and unacceptable to employees (Wiese \& Buckley, 1998). Yazid, Abdullah, and Baharom (2017) indicated that PAS is a difficult process, especially by using subjective judgment which is difficult to measure.

Markom et al., (2001) indicated that the burden of national lecturers' working hours exceed the prescribed standard in the university's evaluation system. In addition, most of the lecturers feel that workload and overburdening task lead to fatigue and stress at work (Fejgin et al., 1995: Pastore \& Judd, 1992: Lim \& Leong, 1999). Consequently, this will not only affect their quality of work but also the organization's productivity (Othman \& Halim, 2014). Apart from that, Turk and Roolaht (2006) mentioned there are several universities in Estonia employing unclear and distinctive PAS. Besides that, CEUPACS President Datuk Azih Muda, called the need to review PAS in Malaysian context and emphasized that the system should be reviewed every five (5) years (Berita Harian, 23 Mei 2018).

\section{OBJECTIVES}

The general objective of this study is to explore the first rater officers (FRO's) perspectives on the issues and implications of the application of PAS attributes among academicians in public universities.

Specific objectives are as follow:

1. To identify the common issues related with attributes of PAS among academicians at public universities based on the FRO's perspectives.

2. To identify critical issues related to attributes of PAS among academicians at public universities based on FRO's perspectives.

\section{METHODOLOGY}

This research approach is research onion which was proposed by Saunders et al., (2016). This study was conducted by qualitative research method using semistructured interview technique. Four (4) informants involved in the study were Deputy Deans. Cresswel (2009) suggested that individuals involved in the interviews should consist of three (3) to fifteen (15) members in which the individual group can rejuvenate their life experience. While Barbour (2000), Furgarda and Potts (2015) assert that informants can be made up of one (1) to two (2) only. Table 1 presents the summary of the informants involved in this study.

\section{DATA COLLECTION}

Table 1: First rater officer background

\begin{tabular}{|c|c|c|c|c|c|c|c|c|c|}
\hline$\ddot{z}$ & $\stackrel{\mathscr{\$}}{4}$ & 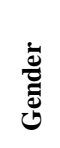 & 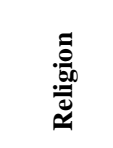 & $\begin{array}{l}\mathscr{\Xi} \\
\text { ๘ }\end{array}$ & 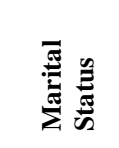 & 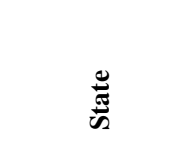 & 氖 & 泀 & 节 \\
\hline 1. & 37 & $\mathrm{~L}$ & Islam & India & Married & Pulau Pinang & $\mathrm{PhD}$ & 14 & Deputy Dean \\
\hline 2. & 43 & $\mathrm{~L}$ & Islam & Bajau & Married & Sabah & $\mathrm{PhD}$ & 17 & Deputy Dean \\
\hline 3. & 40 & $\mathrm{~L}$ & Kristian & Lundayeh & Married & Sabah & $\mathrm{PhD}$ & 6 & Deputy Dean \\
\hline 4. & 44 & $\mathrm{~L}$ & Islam & Melayu & Married & Kuala Lumpur & $\mathrm{PhD}$ & 14 & Deputy Dean \\
\hline
\end{tabular}


The interview sessions took around 40 to 90 minutes per informant. Conversations were recorded by researchers using tape recorders (smartphones) so that the information can be transcribed more easily (Maykut \& Morehouse, 2005).

\section{DATA ANALYSIS}

Qualitative data analysis was conducted using inductive methods known as hermeneutic phenomenology (Saljo, 1982). In this case, the analysis was arranged as display data to serve as final data (Miles, Huberman, \& Saldaña, 2014). In addition, the data collection and analysis performed interactively which was important for theme, pattern and relationship to appear from data collection and analysis (Saunders, Lewis, \& Thornhill, 2009). In order to obtain more valuable information, data obtained through transcripts were divided into several categories and key themes (Denscome, 2007; Cresswell, 2009). Overlapping data reduction techniques were applied to prevent insignificant data. Hence, only important data were processed. In this study, the researcher emphasized the trustworthiness of informants in providing information through several steps such as permission from informants and only informants who volunteered were interviewed and no coercion was made. The ethics of research proposed by (Piaw, 2006) was used as a guideline by the researcher.

\section{RESULTS AND DISCUSSION}

\section{Research Objective 1}

To identify the common issues related with attributes of PAS among academicians at public universities based on the FRO's perspectives.

\section{Result}

The first general issue is about the limitation of the system. Informant one (1) pointed out that the existing system is unable to link with a good database for the purpose of reporting the PAS evidence. Following is the statement of informant one (1):

"...I see the usability of the system is still lacking ... in the system if we can link between one and the other by just one click and everyone can access all the data for the purpose of reporting and evidence..."

Limited system availability issue is also supported by informant three (3) who indicated the system is still weak in terms of data integration and link with the database. Following is the statement of informant three (3).

"... System availability... sometimes our system is not user-friendly... and this complicates our work because our systems are not fully integrated system...yet auto link data in the database ..."

The second general issue is about giving lower marks towards lecturers involved with administrative work. Informant two (2) pointed out that the scoring needs to be improved for lecturers involved with administrative work. Following is the statement by informant two (2):

"What needs to be reformed is the marking system ... for example the participation as being deputy dean... they only give us a 
little mark ... so for me this is not a critical issue however it should be revised ..."

The third general issue is related to server competence. The fourth (4) informant explained that the system used by employees sometimes does not function. Following is the statement by informant four (4):

"... Technical ... whether it's in our control or not, that's a different thing... I think this from CICTS ... how to keep our system upto-date or having strength in terms of the server and many more..."

\section{Discussion}

The first general issue of the finding is the system limitation in terms of its availability. According to Rahman et al. (2017) collaboratively with the current trend, technology cannot be dissociated with the organization. Rusdi, Ashaari, and Noor (2017) suggested usability comes from user-friendly words. This, in line with the findings of Kosasi (2002), agreed that a well-functioning system feature consists of excellent integration, is user-friendly, and the ability to auto link data in the system. The finding of this study was also supported by Tripathi and Pandey (2010) who claimed that the development of web portals required the interface that have high availability. Asiimwe and Lim (2010) argued that user-friendly systems assisted the users to navigate the portal seamlessly as well as strengthen the relationship and encouraging continuous distribution of information to users. In addition, according to Norsidah (2014), the limited availability of the system resulted in lack of quality in an interaction. Furthermore, Othman and Halim (2014) in their study emphasized that by 2020 the government has targeted all universities to become a hub of educational excellence in the international region. Accordingly, many things have been emphasized and among them are the requirement to reinforce information technology as well as communication skills within the organization. This is compatible with the Public Service Department's (2011) recommendation that the heads of departments and rater officers should optimally utilize the technology to achieve organizational objectives.

The second general issue of the findings is lower marks given towards lecturers involved with administrative work. Markom et al., (2001) stressed that previous studies indicate the burden of national lecturers' working hours exceed the prescribed standard in the university's evaluation system. In addition, most of the lecturers feel that workload and overburdening task lead to fatigue and stress at work (Fejgin et al., 1995: Pastore \& Judd, 1992: Lim \& Leong, 1999). Consequently, this will not only affect their quality of work but also the organization's productivity (Othman \& Halim, 2014).

The third general issue is due to server competence. A sophisticated technology should be accompanied by appropriate hardware, software, applications, services, and networks to facilitate work that involves online systems. Surat Pekeliling Am Bilangan No. 3 (2015) in the 21st century ICT development proposed the server configuration must be strong as mentioned in the Pekeliling, "should be able to sustain application requirement for certain period of time". Public Service Department (2009) in the book titled Human Resource Management Information System (HRMIS) of the 21 st century Malaysian public sector human 
resource management transformation that HRMIS database engine or server has undergone changes according to current technology circulation from SQL server 7.0 to Microsoft SQL server 2000 and Microsoft SQL 2003 in line with the development of computer operating system and software. Along with these changes, it has brought advantages to the organization such as periodic and ad-hoc reports in proportion to organizational requirements, equip and develop periodic reports, expedite the release of periodic reports and facilitate the process of reporting data work within organizations that are able to be accessed fast and flexibly by using a web browser such as Internet Explorer (Public Service Department, 2005).

Figure 1 reports a summary of the findings of a general issue in graphic form.
To identify critical issues related to attributes of PAS among academicians at public universities based on FRO's perspectives.

\section{Result}

The first critical issue is the subjective assessment of employees' personality. Informant one stressed that a method should be designed quickly to overcome problems related to assessment of employees' personality. The following is the statement of informant one (1):

"... Only the personality that is subjective and necessary to overcome it immediately ..."

This issue is also supported by informant two (2) who stated that critical issues are subjective assessment points. The following is the statement of informant two (2):

"...if it is urgent I kind of agree with the

\section{Research Objective 2}

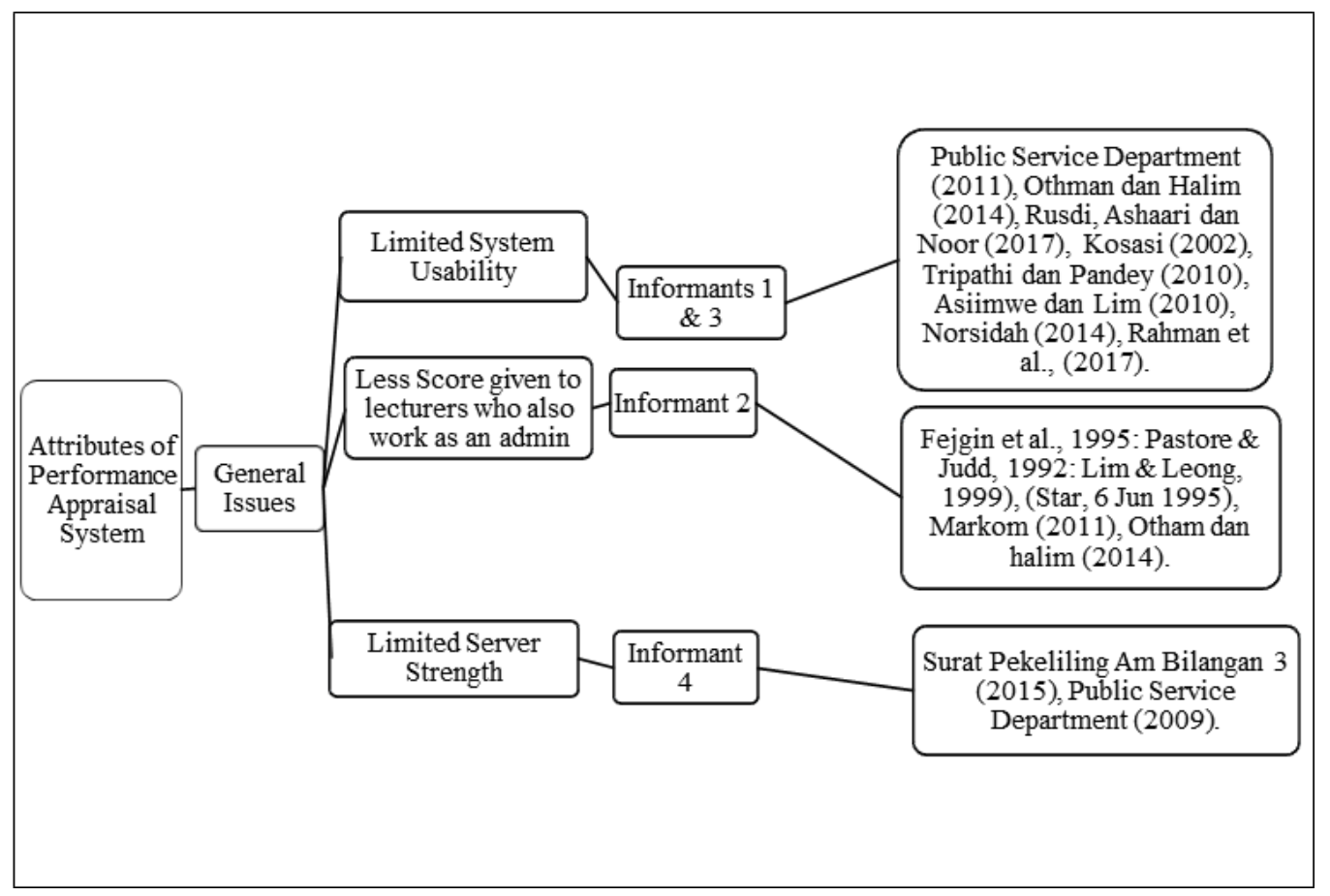

Figure 1: General issue in PAS based on FRO's perspectives. 
personality... the weakness of this first system is not comprehensive ... I think that personality is the most critical ..."

This issue is also supported by informant four (4). The informant noted that in some cases, first rater officer made subjective judgments to lower the rater's scores. The following is the statement of informant four (4):

"The issue of personality ... yes, this is a serious problem ... there is a case where lecturers got high scores in other section but got a low score for personality part ..."

The second critical issue is the limited system. Informant four (4) stated that the system used is unable to retrieve the data from the HRIS. Additionally, he pointed out that the online system applied was still using the old manual system. The following is the statement of informant (4):

"... The availability of the system ... this means our system is unable to retrieve the data in the HRIS ... the promotion form also not the same as the manual evaluation form that was used in this case ... this means the system is fully functioned ..."

\section{Discussion}

The first critical issue for the findings is the subjective assessment of the personality aspect. Folger and Kanovsky (1989) emphasized that an appraisal officer should act more professionally to identify facts by evaluating employee's achievements precisely based on valid and credible measurement criteria. Zulbasri and Bakar (2017) explained that a subjective assessment will lead to tension and conflicts until the activi- ties become unpleasant and ineffective. In addition, Robert (1992) acknowledged that the implementation of FRO's that is more subjective creates tension and causing PAS activities turn out unpleasant and not accepted by employees (Wiese \& Buckley, 1998). Yazid, Abdullah, and Baharom (2017) argued that PAS is a difficult process, especially by using subjective judgment which is difficult to measure. Findings of this study are also supported by the Public Service Department's (2011) claim in the PAS guidelines that RO's should create an objective, fair and transparent evaluation of the employee's career development.

The second critical issue of the findings was the limited availability of the system. According to Rusdi, Ashaari and Noor (2017), the concept of availability is derived from user-friendly words. This, in line with the findings of Kosasi (2002), stated that good system features can work well in terms of integration, user-friendliness and auto-link data feature in the system. Tripathi and Pandey (2010) agreed that the web portal development required interface equipment that have high availability. According to Asiimwe and Lim (2010), user-friendly interface and systems can help users to navigate the portal seamlessly. This can enhance relationships and encourage continuous sharing of information to users. In addition, Norsidah (2014) stated that limited system availability issues resulted in lack of quality for interaction medium. Furthermore, Othman and Halim (2014) in their study stressed that by 2020 , the government has targeted every university to become a hub of educational excellence in the international region. In line with that goal, many things have been highlighted. Public Service Department (2011) stressed on heads of de- 
partments and appraisal officers optimally utilizing the technology to achieve organizational objectives.

Figure 2 reports a summary of the findings of a general issue in the graphical form.

\section{IMPLICATIONS OF STUDY}

Implications are discussed based on issues arising from research and discussion beforehand. The implications of the discussion are on the team of workers, working groups and organizations.

The implications faced by the team of workers when the system is not fully functioning is that the work in the organization will be disrupted. The same implication will occur with the worker group which is work disruption due to system not functioning optimally. Thus, this negatively affects the organization in terms of systematic work and quality of work. Additionally, this also delays the work processes made within the organization. The issue of minimal scoring to the team of employees involved with administrative work leads workers' dissatis- faction because the scoring distribution in PAS is not satisfactory. For the working group, they have difficulties in managing the employees due the dissatisfaction from the workers. This leads to negative impact on the organization in many aspects such as the damaged image of the organization and the negative perspective of the organization by the employees.

One of the implication for the critical issue of the subjective assessment section of the personality aspect is dissatisfaction of workers with scores given primarily involving unbiased judgments. For the working group, it is difficult to assess because there is no clear assessment section for conducting the assessment. Job seekers are not interested with this type of organization as they manage their PAS poorly. This also creates frustration to the employees in the organization. The last critical issue is about the limitations of system functions within the organization. This indicates that the team workers in terms of work being implemented in the disrupted organization. In addition, this also delays the work process especially involving computers. For the

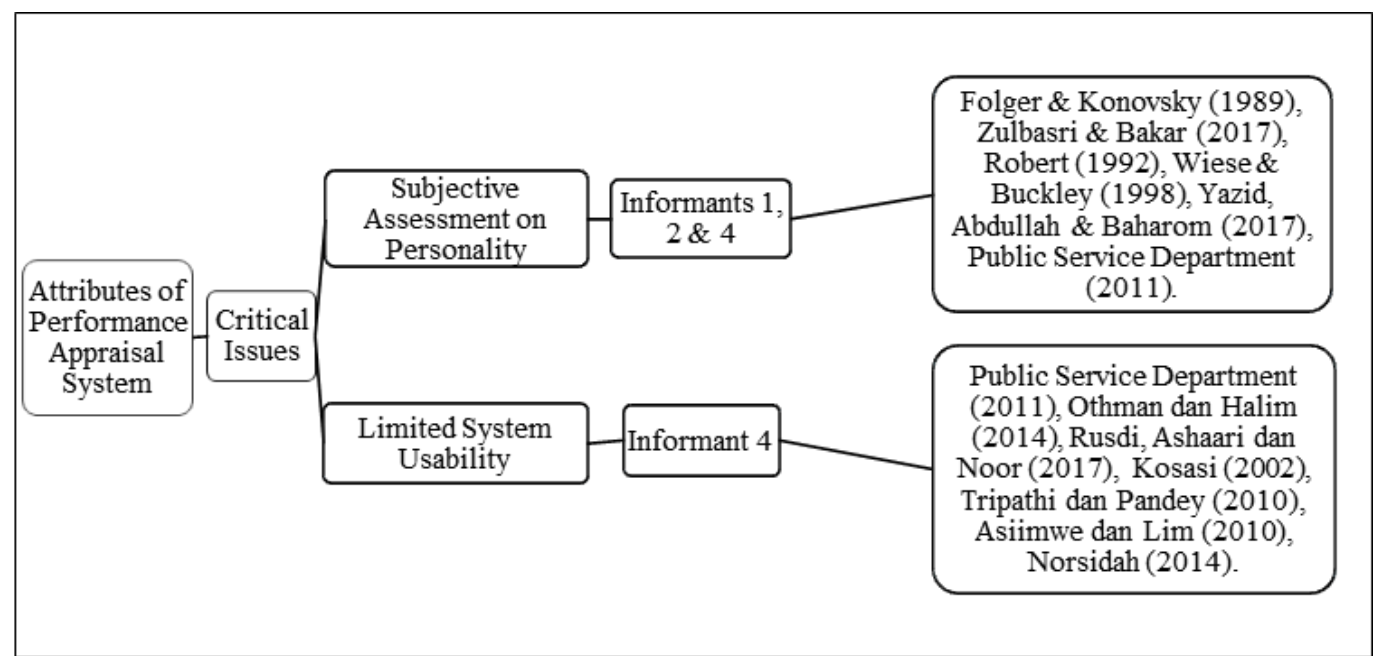

Figure 2: Critical issues in PAS based on first rater officer perspective 
working group, negative implications such as work that require monthly and annual reports will be disrupted as the system does not function optimally. Subsequently, the implications for the organization leads to the overall process of organizational work being interrupted and reduces the quality and productivity in the organization.

\section{RECOMMENDATIONS}

The recommendation divided into two, which are recommendation for human resource practitioners and recommendation for future research.

Human resource practitioners need to be serious about application attributes and they need to emphasize that this is the most important factor in an organization. Although PAS is a small part in HRM, it plays an important role in an organization. If PAS is not well managed, it can cause employee dissatisfaction and many other negative effects. Apart from that, human resource practitioners should also review and clarify the issues raised in subsequent research strategies addressing the critical issues and general issues raised in the research. At the same time, looking at FRO competency, the issue in PAS is especially critical namely in the personality assessment aspect. However, the most important aspect of the appraisal is the application attributes that need to be practiced as a whole in the organization, especially the FRO, SRO and RO. By practicing this in the organization, employees will be more motivated, satisfied and thus improve productivity in the organization. Finally, every usable recommendations for increased PAS in the organization, especially in public universities, should be discussed and implementations of such measures must be ensured in the faculty level to ensure the effectiveness of PAS continues to increase and ensure employee satisfaction and employee motivation in the organization. This is important because it not only makes employees more loyal to the organization, but is able to produce contingent productivity as a result of high employee commitment to the task in the organization.

Further studies need to be conducted in terms relationship of attributes with employee satisfaction in the private sector. Studies can also be done in primary and secondary schools and in private universities. Researchers only conducted studies on aspects of PAS attribute applications at public universities. Hence, qualitative studies can also be conducted to obtain employee reactions to PAS attributes application with the satisfaction of employees in schools, other public universities and private universities. In addition, quantitative and qualitative research can also be made for the perspective of non-academic groups in public and private sectors. The location of the study can also be expanded to take perspective from the public and private sectors. The next researcher is also recommended to study the triangulation method which is using quantitative and qualitative methodologies. At the same time, future researchers are advised to look and compare those attributes in the West Malaysia context to see the suitability of their use. Finally, it is hoped that a deeper and more extensive study can be conducted on six attributes in PAS with more effective techniques.

\section{CONCLUSION}

Overall, the study has identified the issues that exist in the attributes of PAS in public 
universities in Sarawak. The common issues are the limitation of the system availability, insufficient scoring distribution towards lecturers who are involved in administration's work, the limited authority given to FRO's, and limited capability of the server. Along with that, two other critical issues are the subjective judgment of personality traits and limited utilization of the system. Therefore, by taking these issues seriously, every organization can increase their employees' satisfaction, motivation, as well as their productivity within the organization. If these issues are left prolonged, it can cause conflict within the organization that can lead to a lot negative impacts.

\section{REFERENCES}

Ahmad, R., \& Shamsuddin, S. (2011). Pengurusan dan penilaian prestasi pekerja. Kuching, Sarawak: RS Publication.

Asiimwe, E. N., \& Lim, N. (2010). Usability of government websites in Uganda. Electronic Journal of $e$ Government, 8(1), 1-12.

Ahmad, R., Ali, N. A., Ismail, W. K. (2007). Sistem penilaian prestasi sektor awam Malasia: Pemikiran semula terhadap peranan dan tanggungjawab pegawai penilai prestasi. Jurnal Kemanusian, 1(3), 67-23.

Ahmad, R., \& Ismail, A. (2007). Sistem penilaian prestasi di sektor awam di Malaysia: Pemikiran semula terhadap peranan dan tanggungjawab pegawai penilai prestasi. Jurnal Kemanusiaan, 10(1) 90-100.

Abdullah, A. S. (2004). Kepimpinan unggul tonggak pengurusan pendidikan cemerlang. Jurnal Pengurusan dan Kepimpinan Pendidikan, 14(7), 1832.

Brooks, A. (2006). Dispelling HR's fear of technology takeover. Employee Benefit Plan Review, 60(10), 6-10.

Berita Harian (2018). CEUPACS rayu kerajaan laksanakan KGT. Kuala Lumpur: Jabatan Percetakan Negara.

Barbour, R. S. (2000). The role of qualitative research in broadening the evidence base for clinical practice. Journal of Evaluation in Clinical Practice, 6(2), 155-163.

Creswell, J. W. (2009). Research Design. Research Design: Qualitative, Quantitative and Mixed Approaches. Thousand Oaks, CA: Sage.

Creswell, J. W. (2009). Qualitative, quantitative and mixed method (3th ed.). California: SAGE Publication. Inc.

Denscombe, M. (2007). The good research guide (3th ed.). McGraw-Hill Education.

Fugarda, A. J., \& Potts, H. W. (2015). Supporting thinking on sample sizes for thematic analyses: a quantitative tool. International Journal of Social Research Methodology, 8(2)1-16.

Fejgin, N., Ephraty, N., \& Kben-sira, D. (1995). Work environment and burnout of physical education teachers. Journal of Teaching Physical Education, 15(9), 64-78.

Folger, R. \& Kanovsky (1989). Effect of procedural and distributive justice on reaction to pay raise decision. Academy of Management Journal, 32(1), 115-130. 
Kuvaas, B. (2006). Different relationships between perceptions of developmental performance appraisal and work performance. Personnel Review, 36(3), 378-397.

Kosasi, S. (2002). Peranan teknologi informasi dalam pengembangan organisasi. Article Sekolah Tinggi Manajemen Informatika dan Komputer, 8(1), 0854-9524.

Miles, M. B., Huberman, A. M., \& Saldaña, J. (2014). Qualitative data analysis: a methods sourcebook (3 rd ed.). Thousand Oaks, California: SAGE Publications, Inc.

Markom, M., Abdul, N. A., Ariffin, A. K., Wahab, D. A., Husain, H., \& Ramli, N. F. L. (2011). Seminar Pendidikan Kejuruteraan dan Alam Bina. Kongress pengajaran dan pembelajaran UKM.

Maykut, P., \& Morehouse, R. (2005). Beginning Qualitative Research: A Philosophic and Practical Guide. London: The Falmer Press (Taylor \& Francis Group).

Norsidah, T. (2014). Garis Panduan Kebolehgunaan Praktikal Bagi Pembangunan Laman Web e-Kerajaan. Tesis Sarjana. Fakulti Teknologi dan Sains Maklumat, Universiti Kebangsaan Malaysia.

Othman, M. A., \& Halim, F. W. (2014). Pengaruh personaliti terhadap penilaian prestasi kerja berkesan kakitangan akademik UKM. Jurnal Psikologi Malaysia, 28(2), 63-84.

Public Service Department (2011). (Pekeliling Perkhidmatan Bilangan 4/2011).
Public Service Department (2010). (Pekeliling Perkhidmatan Bilangan 13/2010).

Public Service Department Malaysia (2009). HRMIS tranformasi pengurusan sumber manusia sektor awam Malaysia abad ke-21. Kuala Lumpur: MPH Group Printing (M) Sdn Bhd.

Public Service Department (2005). (Pekeliling Kemajuan Pentadbiran Awam Bilangan 2/2005).

Piaw, C. Y. (2006). Kaedah penyelidikan. Malaysia: McGraw-Hill Malaysi Sdn. Bhd.

Rahman, R., Basri, M., Husain, K., Shamsul, C. W., Ahmad, B. C. W., \& Danuri, M. S. N. (2017). Teknologi maklumat dan komunikasi (ICT) dalam kehidupan insan: Integrasi konsep dualiti (Konvensional dan Islam) dalam silibus kursus pengantar IT. Jurnal Sultan Alauddin Sulaiman Shah, 4(1), 2289-8042.

Rusdi, R., Ashaari, N. S., \& Noor, S. F M. (2017). Usability guidelines for elderly website interface. Journal of Information Technology and Multimedia, 6(2), 228-2192.

Robert, G. (1992). Linkages between performance appraisal effectiveness. Review of Public Personnel Administration, 12(3), 19-15.

Saunders, M., Lewis, P., \& Thornhill, A. (2009). Research Methods for Business Students (Fifth ed.). Essex, England: Pearson Education Limited.

Saldaña, J. (2009). The Coding Manual for Qualitative Researchers. London: SAGE Publications Ltd. 
Shaari, A. S., Tang, S. W., Lim, K. T., Yusof, A. A., \& Khan, M. K. J. (2008). Keadilan penilaian prestasi dalam kalangan guru dan hubungannya dengan motivasi kerja dan prestasi akademik sekolah. International Journal of Management Studies, 15(9), 159-176.

Soete, L. L. (2001). ICTs, knowledge work and employement: The challenge to Europe. International labour Review, 140(8), 43-163.

Saunders, M., Lewis, P., \& Thornhill, A. (2016). Research method for business students (7th ed.). United Kingdom: Pitman publishing imprint.

Saljo, R. (1982). Learning and understanding: A study of different in constructing meaning from a text. (Gotoborg Studies in Educational Sciences 41). Gotoborg: Acta Universtitatis Gothoburgensis.

Tripathi, P., \& Pandey, M. (2010). Towards the Identification of Usability Metrics for Academic Web-sites. The 2nd In- ternational Conference on Computer and Automation Engineering (ICCAE), 26-28 February 2010, Singapore.

Veloo, A., \& Zolkepli, W. H. (2011). Atribut sistem penilaian prestasi dengan kepuasan kerja dalam kalangan guru. International Journal of Management Studies, 18(1), 197-216.

Yazid, Z., Abdullah, N. A., \& Baharom, R. (2017). Konflik dalam penilaian proses penilaian prestasi dalam organisasi. Jurnal Pengurusan, 49(7) 41-52.

Wiese, D. S., \& Buckley, M. R. (1998). The evolution of performance appraisal process. Journal of Management History, 4(3), 233-249.

Zulbasri, Z. A., \& Bakar, N. R. A. (2017). Keadilan dalam penilaian prestasi dan komitmen kerja di kalangan kakitangan akademik di sebuah IPTS. International Conference on Management and Muamalah, 2017(4), 978-967. 